\title{
Nitrogenous and phosphorous waste production in a flow-through land-based farm of European seabass (Dicentrarchus labrax)
}

\author{
Gilles Lemarié $^{\left(1_{*}\right)}$, Jean-Louis M. Martin ${ }^{(2)}$, Gilbert Dutto ${ }^{(1)}$, Cécile Garidou ${ }^{(1)}$ \\ (1) Station Ifremer, Chemin de Maguelonne, 34250 Palavas-les-flots, France. \\ (2) Crema-L'Houmeau, 17137 L'Houmeau, France.
}

Received January 21, 1998; accepted June 8, 1998.

\begin{abstract}
A study on nitrogenous and phosphorous waste production in European seabass (Dicentrarchus labrax) was carried out in a flow-through land-based farm. The main objectives were (i) to calculate nitrogenous $(\mathrm{N})$ and phosphorous $(\mathrm{P})$ waste production (particulate and dissolved) from in situ measurements for different rearing ponds with specific fish biomasses, fish sizes and flow rates, (ii) to establish nitrogenous and phosphorous waste production budgets, ratios and equations, and (iii) to compare, for the whole farm, in situ measurements to estimate $\mathrm{N}$ and $\mathrm{P}$ waste production from waste equations. Waste production was manifest by an increase in concentrations of total ammonia nitrogen, total Kjeldhal nitrogen, particulate nitrogen, dissolved phosphorus and total phosphorus concentrations in the outlet water compared to the inlet water for both batches and whole farm. However, no production of nitrite or nitrate was observed. In our budgets, the $\mathbf{N}$ and $\mathbf{P}$ amounts from biomass gains and wastes were explained by the $\mathrm{N}$ and $P$ derived from feed over the range $83.9-105.2 \%$ and $66.5-104.6 \%$ respectively, depending on the fish batch. Values were respectively 103.4 and $87.5 \%$ for the same calculations in the farm. When the whole-farm waste production was calculated from previous equations derived from batches, and then compared with the measured data, the percentages of recovery (estimated by the ratio predicted data/measured data) were 88 and $94 \%$ for total- $\mathrm{N}$ and total-P respectively. $\odot$ Ifremer/Elscvicr, Paris
\end{abstract}

Fish farm waste / excretion / nitrogenous budget / phosphorous budget / Dicentrarchus labrax

Résumé - Quantification des rejets azotés et phosphorés d'une ferme d'élevage en bassins de bars Dicentrarchus labrax. L'étude de la production des déchets (azote et phosphore) d'une ferme de production de bars (Dicentrarchus labrax) est réalisée. Cette étude à pour objectif (i) de mesurer in situ la production des déchets azotés et phosphorés sous forme particulaire et soluble, pour différents bassins d'élevage présentant des caractéristiques variables en terme de biomasse de poisson, de taille des poissons, de débit de l'eau de renouvellement, (ii) d'établir des équations de production de déchets à partir des données précédemment acquises, (iii) de comparer, pour l'ensemble des rejets au niveau de la ferme, les résultats obtenus par des mesures in situ, d'une part, et à l'aide des équations, d'autre part. La production de déchets se traduit par une augmentation des concentrations de l'azote particulaire, de l'azote ammoniacal, de l'azote organique dissous, ainsi que du phosphore particulaire et dissous. Aucune augmentation des nitrates et nitrites In'est observée. L'établissement des budgets d'azote et de phosphore permettent de rendre compte, selon les bassins, du devenir de 88,2 à 105,2\% de l'azote et de 66,2 à 104,6\% du phosphore introduits dans les bassins sous forme de nourriture en granulés. L'étude des budgets réalisée par les deux méthodes (mesures in situ et utilisation des équations) montre que les budgets établis à l'aide des équations rendent compte respectivement de 88 et $94 \%$ de récupération de l'azote et du phosphore. Ces résultats sont respectivement de 103,4 et $87,5 \%$ lorsqu'ils sont établis par des mesures in situ. (C) Ifremer/Elsevier, Paris

Rejets d'aquaculture / excrétion / ammoniaque / phosphore / Dicentrarchus labrax

\section{INTRODUCTION}

Nitrogenous and phosphorous compounds are the main waste products of fish farms [11]. In teleost fish, ammonia and urea are excreted mainly through the gills as end-products of protein catabolism, while phosphate and urea are also excreted by the kidney. Ammonia usually represents 75 to $90 \%$ of the total nitrogenous loss [12]. Faecal losses resulting from unmetabolized food passing through the gut include nitrogenous and phosphorous compounds in concentrations that depend on the digestibility of the raw material [15].

Seabass farming is developing fast in Mediterranean countries, using both sea cages and flow-through 
land-based systems. Metabolic waste concentrations may reach high levels in tanks, and thereby limit fish survival and growth [18], as well as harming the environment by discharging the enriched water from tanks. Quantification of fish waste productions is required to monitor such risks and to develop integrated highdensity culture systems using recirculating water. Although many studies have been carried out to evaluate nutrient loading from salmonid farms in fresh and marine waters $[4,9,10,14]$, no data are yet available for seabass farm effluents. The purpose of the present study is to propose simple ratios and equations for nitrogenous and phosphorous waste production by seabass in relation to both the quantity of ingested feed and the mean weight of the fish. The ratios and equations were obtained by determining $\mathrm{N}$ and $\mathrm{P}$ inputs and outputs and by establishing $\mathrm{N}$ and $\mathrm{P}$ mass conservation equations for 4 seabass batches with different mean weights in a land-based brackish-water farm. Furthermore, the waste production of the whole fish farm, calculated from previous equations, is compared with the waste production determined from field data.

\section{MATERIAL AND METHOD}

The land-based fish farm was on the French Mediterranean seashore near Perpignan. The total volume of water used for rearing was $3000 \mathrm{~m}^{3}$ divided among 10 concrete raceways (each $60 \times 5 \times 1 \mathrm{~m}$ ), which could be divided by using moving screens, depending on the characteristics of the fish batches. The water, from a large karstic spring, was brackish $\left(5 \mathrm{~g} \cdot \mathrm{L}^{-1}\right)$. The $\mathrm{pH}$ was stable (7.3) and the temperature ranged from 16.5 to $18.5^{\circ} \mathrm{C}$ during the year. Before use, the pumped water was degassed in a special vacuum device and oxygenated at $125-130 \%$ saturation. The average water renewal rate was $150 \% \cdot \mathrm{h}^{-1}$ in the flowthrough farm. Batches of 1-g weaned juvenile seabass were delivered all year round by different hatcheries. The annual production of the farm was about $100 \mathrm{t}$ of $350-400 \mathrm{~g}$ fish after a 24-26-month rearing period. The average fish stocking density ranged from 25 to $50 \mathrm{~kg} \cdot \mathrm{m}^{-3}$. Combined with the high renewal rate of the water, this densitiy reduced the sinking and prevented the stagnation of suspended solids and/or particulate matter in the tanks. At the start of the experiment, 17 different batches of seabass were present in the farm, representing $121210^{3}$ fish corresponding to a total biomass of $119 \mathrm{t}$. The number of fish per batch ranged from 6250 to 296800 and the mean weight ranged from 4.2 to $365 \mathrm{~g}$.

The fish were fed ECOLINE ${ }^{\circledR}$ pellets ( $48 \%$ proteins, $20 \%$ lipids) adapted to the fish size. The daily quantity per batch was calculated from feeding tables on a 15-day basis and delivered by self-feeders filled up at 09:00 h. The feeding conversion ratio (quantity of feed divided by the biomass produced) was 1.8 on a 100 - $t$ yearly production basis.
In order to calculate the waste production ratios and equations, 4 batches (A, B, C, D) of seabass at different mean weights $(22,51,100$ and $340 \mathrm{~g}$, respectively) were selected and mass balance equations were established for nitrogen and phosphorus during a sampling period $t$ ( $31,30,31$ and 30 days, respectively) required for a significant growth, as:

$$
\text { Feed }_{t}=\text { Fish }_{t}+\mathbf{R}_{t}
$$

where Feed ${ }_{t}=$ total feed supplied during the period $t$ expressed in $\mathrm{kg}$ of nitrogen or phosphorus, Fish $=$ fish production expressed in $\mathrm{kg}$ of nitrogen or phosphorus during the period $t$ and $\mathrm{R}_{t}=$ waste production expressed in $\mathrm{kg}$ of nitrogen or phosphorus during the period $t$.

The fish production or biomass gain was calculated from the difference between the final biomass $\left(\mathrm{B}_{f}=n_{f} \times \mathrm{W}_{f}\right)$ and the initial biomass $\left(\mathrm{B}_{i}=n_{i} \times \mathrm{W}_{i}\right)$ of a period $t$ where $n_{f}$ and $n_{i}$ were the final and initial number of fish in the batch and $\mathrm{W}_{f}$ and $\mathrm{W}_{i}$ the final and initial mean weights of fish. An estimate of the biomass gain corresponding to the dead fish was added to the previous result. The waste production $R_{\text {, was the sum }}$ of particulate matter and dissolved compounds ( $m i n-$ eral + organic), in the water volume $\mathrm{V}$ passing through the raceway during the period $t$, as $\mathrm{R}_{t}=\mathrm{V} \times\left(\mathrm{C}_{o}-\mathrm{C}_{i}\right)$ where $\mathrm{C}_{o}$ and $\mathrm{C}_{i}$ were the outlet and inlet concentrations of particulate matter and dissolved compounds and $\mathrm{V}=\mathrm{F} \times t$, where $\mathrm{F}$ was the flow rate and $t$ was time. A mass balance equation was also established for the whole farm during a 61-day sampling period using the same methodology.

Data concerning fish mean weights and numbers (incoming juveniles, batches, mortalities), feed (delivered daily quantity per batch) and flow rate were taken from the files of the farm. Nitrogen and phosphorus of feed, fish, particulate matter and dissolved compounds were determined from aliquots of samples taken using various sampling methodologies described hereunder. In feed meant for each batch of fish, random 50-g samples of pellets were pooled from each $25-\mathrm{kg}$ bag used during the period $t$. Per batch, $2 \mathrm{~kg}$ of fish biomass were sampled randomly on the first day (d1) and last (d30 or d31) day of the period. The inlet water was continuously sampled by gravity during a 24-h period at d1, 8, 15, 21 and 30 or 31 at the water intake of the farm. For each batch of fish, water samples of $0.5 \mathrm{~L}$, taken every $2 \mathrm{~h}$ from the outlet with a peristaltic pump, were pooled over a 24 -h period on $\mathrm{d} 1,8,15,21,30$ or 31 , after setting up a special device for homogenizing particles in water at the end of the race-way. This device was made of two vertical and convergent wooden panels driving water through a pipe fitted with a large air bubble diffuser.

In order to establish the $\mathrm{N}$ and $\mathrm{P}$ mass conservation equations for the whole farm, random feed samples of $50 \mathrm{~g}$ from one in every ten bags of the present feed stock in the farm were pooled on the first (d1) and last (d61) day of the period. Each batch of feed delivered 
(usually every fortnight) was sampled similarly during the whole period. One hundred g samples of fish biomass were randomly taken for analysis from incoming batches of juveniles, and, for the larger fish, $5 \mathrm{~kg}$ of biomass were proportionally randomly taken from the 17 batches on the first (d1) and last (d61) day of the period. Farm inlet water was continuously sampled by gravity during a $24-\mathrm{h}$ period every 7 days during the 61-d period of the experiment, while outlet water was sampled at the same frequency by pooling $2 \mathrm{~L}$ of water taken every $2 \mathrm{~h}$ using gravity over a $24-\mathrm{h}$ period. Before analysis, the feed samples were ground finely; the samples of fish were frozen, ground finely and freeze dried. The water sample aliquots were filtered through pre-combusted $\left(450^{\circ} \mathrm{C}\right.$ for $4 \mathrm{~h}$ ) GFC What$\operatorname{man}^{\circledR} 1.2 \mu \mathrm{m}$ filters, in order to analyse dissolved compounds and particulate nitrogen and phosphorus.

In the feed, fish and the particulate matter, nitrogen (Feed-N, Fish-N and Particulate- $\mathrm{N}$ respectively) was determined using a gas chromatograph carbon/nitrogen analyser Carlo Erba ${ }^{\circledR} 1500$ [13]. In water samples, dissolved inorganic nitrogen, total ammonia nitrogen (TA-N), nitrite nitrogen $\left(\mathrm{NO}_{2}^{2-}-\mathrm{N}\right)$ and nitrate nitrogen $\left(\mathrm{NO}_{3}^{-}-\mathrm{N}\right)$ concentrations were determined after filtration by colorimetric methods using an autoanalyser with continuous flow $[3,17,22,23]$. The total Kjeldahl nitrogen (TK-N) concentrations were determined by Kjeldhal's colorimetric method which measures the sum of nitrogen as both ammonia and organic forms (including urea). TK-N allows the total dissolved organic nitrogen (DO-N) to be calculated as the difference between TK-N and TA-N. Phosphorus analysis was done on filtered (Dissolved-P) and unfiltered (Total-P) water samples, after treatment with sulphuric acid, using the colorimetric method [21]. Particulate-P could be obtained by difference subtraction of Total-P and Dissolved-P.

\section{RESULTS}

Table I shows the principle results concerning the different batches of fish, as well as some characteristics of the fish farm. These data allow the calculation of the mass conservation equations for nitrogen and phosphorus. It is to be noticed that the specific growth rates and the food conversion ratios of the selected batches of seabass were in accordance with those regularly observed in the farm. Mortality was low and ranged from 0.13 to $0.57 \%$ over periods of about onemonth, and was $1.04 \%$ over 2 months. The leaching index represents the residence of the water $\times$ the stocking density of fish. It shows values ranging from 9 to 31 for the batches, but was 33 for the whole farm.

Table II shows the nitrogen and phosphorus concentrations in the components, feed, fish and water, in order to establish the equations of mass conservation. The nitrogen and phosphorus content in feed and fish were expressed in terms of feed and live biomass, respectively. The nitrogen content of feed was similar for different batches and for the whole farm. Some variations appeared in fish between batches. The phosphorus concentrations in the feed were quite similar for the different batches and for the whole farm. The nitrogen and phosphorus concentrations in the feed were respectively 5.3 and 1.8 times higher than those in fish.

Table I. Rearing data of fish batches and farm.

\begin{tabular}{|c|c|c|c|c|c|}
\hline & Batch A & Batch B & Batch C & Batch D & Farm \\
\hline Sampling period in days & 30 & 31 & 30 & 31 & 61 \\
\hline Rearing volume $\left(\mathrm{m}^{3}\right)$ & 68 & 134 & 300 & 210 & 3000 \\
\hline Feed (total delivered quantity in $\mathrm{kg}$ ) & 645 & 1200 & 3250 & 1285 & 55637 \\
\hline \multicolumn{6}{|l|}{ Fish } \\
\hline Initial mean weight (g) & 22 & 51 & 100 & 340 & - \\
\hline Final mean weight $(\mathrm{g})$ & 27 & 64 & 121 & 385 & - \\
\hline Initial number & 75979 & 62913 & 107771 & 21993 & - \\
\hline Final number & 75574 & 62834 & 107451 & 21867 & - \\
\hline Mortality (\%) & 0.53 & 0.13 & 0.30 & 0.57 & 1.04 \\
\hline Initial biomass $(\mathrm{kg})$ & 1672 & 3209 & 10777 & 7478 & 119036 \\
\hline Final biomass (kg) & 2040 & 4021 & 13002 & 8419 & $141360^{a}$ \\
\hline Biomass gain $(\mathrm{kg})$ & 368 & 812 & 2225 & 941 & $22324^{a}$ \\
\hline Specific growth rate $\left(\% \cdot d^{-1}\right)$ & 0.68 & 0.73 & 0.64 & 0.40 & - \\
\hline Food conversion ratio & 1.75 & 1.48 & 1.46 & 1.37 & 2.4 \\
\hline Stocking density $\left(\mathrm{kg} \cdot \mathrm{m}^{-3}\right)$ & 31 & 30 & 45 & 41 & 47 \\
\hline \multicolumn{6}{|l|}{ Water } \\
\hline Mean flow rate $\left(\mathrm{m}^{3} \cdot \mathrm{h}^{-1}\right)$ & 135.2 & 411.6 & 430.8 & 392.5 & 4453 \\
\hline Tolal water quantity $\left(\mathrm{m}^{3}\right)$ & 97344 & 306230 & 310176 & 2902002 & 6519192 \\
\hline Residence time $^{b}(h)$ & 0.5 & 0.3 & 0.7 & 0.5 & 0.7 \\
\hline Leaching index ${ }^{c}$ & 15 & 9 & 31 & 20 & 33 \\
\hline
\end{tabular}

ancluding dead and sold fish, excluding incoming juveniles.

${ }^{b}$ Water residence time $=$ rearing volume/flow rate.

${ }^{c}$ Leaching index $=$ water residence time $\times$ fish stocking density.

Aquat. Living Resour. 11 (4) (1998) 
Table II. Nitrogen (N) and phosphorus (P) concentrations in feed, fish and water. Values in feed and fish are expressed as g. $\mathrm{kg}^{-1}$ raw feed or live fish biomass. Values in water (particulate and dissolved) are expressed as $\mathrm{mg} \cdot \mathrm{m}^{-3}$.

\begin{tabular}{|c|c|c|c|c|c|c|}
\hline Feed and fish & & Batch A & Batch B & Batch C & Batch D & Farm \\
\hline Feed-N & & $70.1 \pm 1.7$ & $65.8 \pm 1.5$ & $70.1 \pm 1.8$ & $69.9 \pm 2.1$ & $71.6 \pm 1.9$ \\
\hline Fish-N (initial content) & & $11.0+1.5$ & $11.6 \pm 1.6$ & $15.7+1.8$ & $15.9 \pm 1.6$ & $14.1 \pm 1.3$ \\
\hline Fish-N (final content) & & $11.7 \pm 1.4$ & $12.4 \pm 1.5$ & $15.5 \pm 1.6$ & $15.9 \pm 1.7$ & $14.7 \pm 1.5$ \\
\hline Feed-P & & $10.6 \pm 1.3$ & $11.0 \pm 1.6$ & $11.0 \pm 1.1$ & $10.1 \pm 1.4$ & $11.2 \pm 1.7$ \\
\hline Fish-P (initial content) & & $6.3 \perp 0.1$ & $6.3 \perp 0.1$ & $6.4 \perp 0.2$ & $5.7 \pm 0.1$ & $6.4 \pm 0.7$ \\
\hline Fish-P (final content) & & $6.5 \pm 0.2$ & $6.4 \pm 0.2$ & $5.7 \pm 0.2$ & $5.7 \pm 0.2$ & $6.6 \pm 0.6$ \\
\hline Water & Farm inlet & Outlet A & Outlet B & Outlet C & Outlet D & Farm outlet \\
\hline Particulate-N & $10.6 \pm 2.7$ & $61.9 \pm 20.9$ & $33.6 \pm 7.3$ & $100.0 \pm 41.5$ & $48.3 \pm 8.4$ & $80.4 \pm 13.0$ \\
\hline Total Ammonia-N & $42 \pm 16$ & $250 \pm 65$ & $124 \pm 12$ & $120 \pm 120$ & $166 \pm 89$ & $390 \pm 30$ \\
\hline $\mathrm{NO}_{2}^{2-}-\mathrm{N}$ & $13 \pm 3.6$ & $14 \pm 3.8$ & $12 \pm 4.1$ & $11 \pm 3.2$ & $13 \pm 3.0$ & $17 \pm 3.9$ \\
\hline $\mathrm{NO}_{3}^{-}-\mathrm{N}$ & $1006 \pm 21$ & $998 \pm 25$ & $1013 \pm 27$ & $1017 \pm 19$ & $1008 \pm 20$ & $1021 \pm 14$ \\
\hline Total Kjeldhal-N & $119 \pm 24$ & $401 \pm 113$ & $326 \pm 129$ & $573 \pm 109$ & $341 \pm 124$ & $619 \pm 50$ \\
\hline Dissolved Organic- $\mathrm{N}^{\mathrm{a}}$ & 77 & 151 & 202 & 153 & 175 & 229 \\
\hline Total Dissolved- $\mathrm{N}^{\mathrm{b}}$ & 1138 & 1413 & 1351 & 1601 & 1362 & 1657 \\
\hline Total- $\mathrm{N}^{\mathrm{c}}$ & 1215 & 1564 & 1553 & 1754 & 1537 & 1886 \\
\hline Particulate- $\mathrm{P}^{d}$ & $13.6 \pm 2.6$ & $37.7 \pm 13.2$ & $24.0 \pm 4.6$ & $26.1 \pm 4.1$ & $22.9 \pm 3.7$ & $28.8 \pm 4.2$ \\
\hline Dissolved-P & $34.4 \pm 10.0$ & $50.9 \pm 17.1$ & $44.5 \pm 15.2$ & $81.7 \pm 18.8$ & $52.9 \pm 17.9$ & $76.6 \pm 5.1$ \\
\hline Total-P & $48 \pm 12.6$ & $88.6 \pm 30.3$ & $68.5 \pm 19.8$ & $107.8 \pm 22.9$ & $75.8 \pm 21.6$ & $105.4 \pm 9.3$ \\
\hline
\end{tabular}

${ }^{a}$ Dissolved Organic- $\mathrm{N}=($ Total Kjeldhal-N) $-($ Total Ammonia-N)

b Total Dissolved-N $=\left(\mathrm{NO}_{2}^{2-}-\mathrm{N}+\mathrm{NO}_{3}^{-}-\mathrm{N}+\right.$ Total Kjeldhal- $\left.\mathrm{N}\right)$

c Total- $\mathrm{N}=($ Particulate- $\mathrm{N}+$ Total Dissolved-N)

${ }^{d}$ Particulate- $\mathrm{P}=$ (Total-P - Dissolved-P)

Particulate nitrogen concentrations were higher in the outlet water than in the inlet water. The same was obscrved for TA-N and DO-N. For $\mathrm{NO}_{2}^{2-}-\mathrm{N}$ and $\mathrm{NO}_{3}^{-}-\mathrm{N}$, however, concentrations in the outlet water were similar to those in the inlet water. Concerning phosphorus, both Particulate-P and Dissolved-P increased from the inlet to the outlet. It is underlined that the highest concentrations of Particulate-N, Total Dissolved-N, Total-N, Dissolved-P and Total-P were found in those batches or farm effluents with the highest leaching index, respectively 31 for batch $\mathrm{C}$ and 33 for the whole farm. Correspondingly, the lowest concentrations of these compounds are shown for batch B, which has the lowest leaching index (i.e. 9). Some chlorophyll- $a$ analyses (extraction with methanol then measurement with a fluorimeter) were performed on raceway effluents. Concentrations were always lower than the detection limit $\left(0.5 \mu \mathrm{g} \cdot \mathrm{L}^{-1}\right)$ of the method, indicating that there was no measurable production of phytoplankton inside the rearing raceways.

\subsection{Nitrogenous and phosphorous mass balances}

Table III shows, for both $\mathrm{N}$ and $\mathrm{P}$, the feed quantities delivered in pellet form $\left(\right.$ Feed $\left._{t}\right)$, the fish biomass gain (i.e. fish production) (Fish $_{\text {) }}$ as well as waste production $\left(\mathrm{R}_{t}\right)$ as particulate + dissolved compounds during the sampling period $t$. For each batch of fish, the ratio of $\mathrm{N}$ and $\mathrm{P}$ mass conservation was expressed as $\left(\right.$ Fish $\left._{t}+\mathrm{R}_{t}\right) /$ Feed $_{t}$ in $\%$, and ranged from 83.9 to $112.1 \%$ and from 66.5 to $104.6 \%$ respectively, showing rather balanced budgets. The nitrogen and phosphorus part retained by seabass from feed delivered, expressed by the ratio Fish $_{t} /$ Feed $_{t}$ in $\%$, ranged from
Table III. Nitrogen (N) and phosphorus (P) mass balances.

\begin{tabular}{lrrrrr}
\hline Batch & \multicolumn{1}{c}{ A } & \multicolumn{1}{c}{ B } & \multicolumn{1}{c}{ C } & D & Farm \\
\hline Mean fish weight (g) & 24.5 & 57.5 & 110.5 & 362.5 & \\
Nitrogen & & & & & \\
Feed-N supplied (kg) & 45.2 & 79.0 & 227.8 & 89.8 & 3983 \\
Fish-N production (kg) & 5.5 & 12.6 & 32.3 & 15.0 & 409 \\
Total Waste (R) N production (kg) & 32.4 & 70.4 & 168.5 & 75.8 & 3715 \\
(R-N + Fish-N) / Feed-N (\%) & 83.9 & 105.2 & 88.2 & 101.1 & 103.4 \\
Fish-N / Feed-N (\%) & 12.1 & 16.0 & 14.2 & 16.7 & 10.2 \\
Phosphorus & & & & & \\
Feed-P supplied (kg) & 6.8 & 13.2 & 35.8 & 13.0 & 623 \\
Fish-P production (kg) & 2.7 & 5.5 & 5.1 & 5.4 & 171 \\
Total Waste (R)-P production (kg) & 4.0 & 6.4 & 18.6 & 8.2 & 374 \\
(R-P + Fish-P) / Feed-P (\%) & 98.2 & 90.1 & 66.2 & 104.6 & 87.5 \\
Fish-P / Feed-P (\%) & 39.7 & 41.6 & 14.2 & 41.3 & 27.4 \\
\hline
\end{tabular}

12.1 to $16.7 \%$ (mean $14.8 \%$ ) and from 14.4 to $41.8 \%$ (mean $34.4 \%$ ) respectively without any correlation with the mean weight of the fish.

\subsection{Nitrogenous and phosphorous waste productions}

The waste productions are summarized in table $I V$. The fish mean weight per batch was the mean of the initial and final weight. The values of $\mathrm{N}$ and $\mathrm{P}$ waste production (expressed in $\mathrm{g} \cdot \mathrm{kg}^{-1}$ of feed delivered) were similar and not dependent on fish weight in the different batches for each of the categories TA-N, Particulate-N, Total-N, or Total-P. Mean values were calculated except for DO-N, Dissolved-P and Particulate-P, where data variability was too high. The mean amount of wastes was $29.1 \mathrm{~g} \mathrm{TA}-\mathrm{N}, 18.1 \mathrm{~g}$ DO-N, $7.7 \mathrm{~g}$ Particulate-N, $54.9 \mathrm{~g}$ Total-N and $5.9 \mathrm{~g}$ Total-P for each $\mathrm{kg}$ 
Table IV. Nitrogen and phosphorus waste productions. Between brackets are shown the ratio (\%) of the compounds- $\mathrm{N}$ or -P compared to the total quantity of wastes produced (Total- $\mathrm{N}$ or Total $\mathrm{P} \mathrm{g} \cdot \mathrm{kg}^{-1}$ feed delivered).

\begin{tabular}{|c|c|c|c|c|c|c|}
\hline & Batch A & Batch B & Batch C & Batch D & $\begin{array}{l}\text { Mean values } \\
\text { of batches }\end{array}$ & Farm \\
\hline Mean fish weight $(\mathrm{g})$ & 24.5 & 57.5 & 110.5 & 362.5 & & \\
\hline \multicolumn{7}{|l|}{ Nitrogen waste } \\
\hline Daily TA-N (mg $\cdot \mathrm{kg}^{-1}$ fish) & 363.6 & 241.4 & 328.7 & 147.0 & & \\
\hline TA-N ( $\mathrm{g} \cdot \mathrm{kg}^{-1}$ feed delivered $)$ & $31.4(62)$ & $20.9(38)$ & $36.1(69)$ & $28.2(48)$ & $29.1 \pm 6.2(53)$ & $40.8(61)$ \\
\hline Daily DO-N (mg. $\mathrm{kg}^{-1}$ fish) & 129.4 & 341.6 & 66.1 & 116.1 & & \\
\hline DO- $\mathrm{N}\left(\mathrm{g} \cdot \mathrm{kg}^{-1}\right.$ feed deliv. $)$ & $11.2(22)$ & $31.9(53)$ & $7.3(14)$ & $22.3(38)$ & $18.1 \pm 10.9(33)$ & $17.8(27)$ \\
\hline Daily Particulate-N (mg.kg ${ }^{-1}$ fish) & 89.7 & 62.9 & 77.7 & 44.7 & & \\
\hline Particulate- $\mathrm{N}\left(\mathrm{g} \cdot \mathrm{kg}^{-1}\right.$ feed deliv.) & $7.7(16)$ & $5.9(9)$ & $8.5(17)$ & $8.6(14)$ & $7.7 \pm 1.2(14)$ & $8.1(12)$ \\
\hline Daily Total- $\mathrm{N}^{\mathrm{a}}$ (mg $\cdot \mathrm{kg}^{-1}$ fish) & 582.7 & 628.5 & 472.6 & 307.8 & & \\
\hline Total- $\mathrm{N}^{\mathrm{a}}$ (g. $\mathrm{kg}^{-1}$ feed deliv.) & $50.3(100)$ & $58.7(100)$ & $51.9(100)$ & $59.0(100)$ & $54.9 \pm 4.4(100)$ & $66.7(100)$ \\
\hline \multicolumn{7}{|l|}{ Phosphorus waste } \\
\hline Daily Dissolved-P (mg.kg ${ }^{-1}$ fish) & 19.9 & 19.1 & 28.3 & 14.9 & & \\
\hline Disssolved-P $\left(\mathrm{g} \cdot \mathrm{kg}^{-1}\right.$ feed $)$ & $2.5(40)$ & $2.6(48)$ & $4.5(78)$ & $4.2(66)$ & $3.5 \pm 1.1(58)$ & $4.9(73)$ \\
\hline Daily Particulate-P (mg. $\mathrm{kg}^{-1}$ fish) & 29.4 & 20.3 & 7.7 & 7.7 & & \\
\hline Particulate-P $\left(\mathrm{g} \cdot \mathrm{kg}^{-1}\right.$ feed $)$ & $3.7(60)$ & $2.7(52)$ & $1.2(22)$ & $2.2(34)$ & $2.5 \pm 1.0(42)$ & $1.8(27)$ \\
\hline Daily Total-P $\left(\mathrm{mg} \cdot \mathrm{kg}^{-1} \text { fish }\right)^{\mathrm{b}}$ & 49.3 & 39.4 & 36.0 & 22.6 & & \\
\hline Total-P (g.kg-1 feed $)^{\mathrm{b}}$ & $6.2(100)$ & $5.3(100)$ & $5.7(100)$ & $6.4(100)$ & $5.9 \pm 0.5(100)$ & $6.7(100)$ \\
\hline
\end{tabular}

${ }^{\text {a }}$ Total-N is the sum of Total Ammonia-N (TA-N), Total Dissolved Organic-N (DO-N), and Particulate-N.

${ }^{b}$ Particulate-P is the difference between Total-P and Dissolved-P.

of feed delivered. Farm values, $40.8 \mathrm{~g}$ T $\Lambda-\mathrm{N}, 17.8 \mathrm{~g}$ DO-N, $8.1 \mathrm{~g}$ Particulate-N, $66.7 \mathrm{~g}$ Total-N and $6.7 \mathrm{~g}$ Total-P per $\mathrm{kg}$ of feed delivered, were slightly higher than the mean values for the batches.

When compared to the Total- $\mathrm{N}$ liberated by fish into the water, the percentage of TA-N was not weight dependent and ranged from 38 to $69 \%$ (mean $54 \%$ ) for the batches and was $61 \%$ for the whole farm. The percentage of Particulate- $\mathrm{N}$ compared to the Total-N ranged from 9 to $17 \%$ (mean $14 \%$ ) for the batches and was $12 \%$ for the whole farm. The percentage of DO-N ranged from 14 to $53 \%$ (mean $32 \%$ ) of Total-N for the batches and was $27 \%$ for the farm. For phosphorus concentrations in water, the corresponding ratio of Particulate-P to Total-P was not weight-dependent, ranging from 22 to $60 \%$ (mean $42 \%$ ) for fish batches and was $27 \%$ for the whole farm.

\subsection{Waste production equations in relation to fish mean weight}

Table IV shows that the waste production of TA-N, Particulate- $\mathrm{N}$, Total-N and Total-P expressed in $\mathrm{mg} \cdot \mathrm{kg}^{-1}$ live fish biomass per day, was all inversely related to fish weight.

Table $V$ shows the results of simple linear regression analyses. Significant correlations were found between mean weight and the nitrogenous and phosphorous waste production. Four equations were proposed to estimate nitrogen (TA-N, Particulate-N and Total-N) and phosphorus (Total-P) waste productions as functions of mean fish weight. The general form of these equations is exponential, $y=a \times e^{b x}$ where $y$ is the waste production and $x$ is mean fish weight. Table $V$ shows the values of the factors $a$ and $b$ for each type of waste.
Table V. Values of $a$ and $b$ in the equations of nitrogenous $(\mathrm{N})$ and phosphorous (P) waste production (y, in $\mathrm{mg} \cdot \mathrm{kg}^{-1}$ fish $\left.\cdot \mathrm{day}^{-1}\right)$ in relation with the fish mean weight $\left(x\right.$, in gram), $y=a \times e^{b x}$. Correlation factor $=r^{2}$

\begin{tabular}{lrcc}
\hline$y$ & $a$ & $b$ & $r^{2}$ \\
\hline Total Ammonia-N & 354.1 & -0.0024 & 0.79 \\
Particulate-N & 84.7 & -0.0017 & 0.78 \\
Total-N & 636.6 & -0.0020 & 0.94 \\
Total-P & 47.4 & -0.0021 & 0.95 \\
\hline
\end{tabular}

\subsection{Validation of waste production equations}

The previous equations for Total-N and Total-P waste production, obtained from the results on batches A, B, C, and D (table V), were applied to each of the 17 fish batches present in the farm, using specific biomasses and mean weights. Then, by summation, the predicted Total- $\mathrm{N}$ and Total-P waste productions of the farm were calculated (respectively 3266 and $350 \mathrm{~kg}$ ) and compared to the measured data for the farm shown in table III (3715 and $374 \mathrm{~kg}$ ). The percentages of recovery (estimated by the ratio predicted data/measured data) were 88 and $94 \%$ for Total-N and Total-P, respectively.

\section{DISCUSSION AND CONCLUSION}

Nitrogenous and phosphorous feed contents (66$72 \mathrm{~g} \mathrm{~N} \cdot \mathrm{kg}^{-1}$ and $10-11 \mathrm{~g} \mathrm{P} \cdot \mathrm{kg}^{-1}$ ) were similar to values cited in literature for similar feed: $72-77 \mathrm{~g} \mathrm{~N} \cdot \mathrm{kg}^{-1}$ and $12-14 \mathrm{~g} \mathrm{P} \mathrm{kg}^{-1}$ [8]. For the nitrogenous and phosphorous relative content in seabass, the mean values were 1.38 and $0.62 \%$, respectively, on a wet fish mass basis, similar to the 2.66 and $0.42 \%$ for $\mathrm{N}$ and $\mathrm{P}$ content in rainbow trout (Wallin and Hakanson reported in Eikebrokk and Ulgenes [8]). 
Waste production was manifest by an increase in measured concentrations of TA-N, TK-N, Particulate-N, Total-N, Dissolved-P and Total-P in the outlet water relative to the inlet water both within batches and for the whole farm. However, no production of $\mathrm{NO}_{2}^{2-}-\mathrm{N}$ and $\mathrm{NO}_{3}^{-}-\mathrm{N}$ was observed (same concentration in inlet and outlet water). Clearly the residence time of the water in the batches was too short to allow significant nitrification. The $\mathrm{NO}_{3}^{-}-\mathrm{N}$ concentrations, observed in inlet water, close to $1 \mathrm{mg} \cdot \mathrm{L}^{-1}$, pointed to the karstic origin of the water.

High variability in Dissolved-P and Particulate-P waste production was found within batches, so no ratios or equations could be established. In batches $\mathrm{A}$ and $\mathbf{B}$, production of Particulate-P was higher than Dissolved-P. The opposite was found in batches $\mathrm{C}$ and $\mathrm{D}$, however, suggesting that a partial dissolution of the particulate matter may have occurred in the ambient water, possibly due to leaching after settlement or to more vigorous agitation of the particles in these two raceways. De visu observation did not reveal peculiar accumulation of solid particles anywhere at the bottom of the tanks. But higher leaching in tanks C and D might be suspected when higher fish stocking density and longer water residence time were considered. In fact, the leaching indexes calculated in table 1 were 31 and 20 for tanks C and D respectively, but only 15 and 9 for tanks A and B. These differences in leaching indexes could also explain the variability of concentrations in $\mathrm{N}$ and $\mathrm{P}$ compounds, from one outlet to the other, the highest concentrations (for Particulate- $N$, TA-N, Total Dissolved-N, Total-N, Dissolved-P, TotalP) being observed for the highest leaching indexes.

For similar feed, nitrogen and phosphorus waste production depends on species, mean weight and rearing temperature. The daily Total- $\mathrm{N}$ waste production ranged from 582.7 to $307.8 \mathrm{mg} \mathrm{N} \cdot \mathrm{kg}^{-1}$ fish and daily Total-P waste production ranged from 49.6 to $22.6 \mathrm{mg}$ $\mathrm{P} \cdot \mathrm{kg}^{-1}$ fish in $25-365 \mathrm{~g}$ seabass reared at $17^{\circ} \mathrm{C}$. For example, average values of $160 \mathrm{mg} \mathrm{N} \cdot \mathrm{kg}^{-1}$ fish per day and $32 \mathrm{~g} \mathrm{P} \cdot \mathrm{kg}^{-1}$ fish per day were calculated in an Atlantic salmon farm producing yearly 240 tons where the biomass was mainly represented by classes of the heaviest fish [8]. These estimates are in accordance with other daily production figures for Atlantic salmon (mean weight $=3.8-4.2 \mathrm{~kg}$, temperature $=4{ }^{\circ} \mathrm{C}$ ): $120 \mathrm{mg} \mathrm{N} \cdot \mathrm{kg}^{-1}$ fish and $43 \mathrm{mg} \mathrm{P} \cdot \mathrm{kg}^{-1}$ fish [9]. For arctic charr (mean weight $=50-71 \mathrm{~g}$, temperature $=6^{\circ} \mathrm{C}$ ), the same author found $443 \mathrm{mg} \mathrm{N} \cdot \mathrm{kg}^{-1}$ fish $\cdot \mathrm{d}^{-1}$ and $120 \mathrm{mg} \mathrm{P} \cdot \mathrm{kg}^{-1}$ fish $\cdot \mathrm{d}^{-1}$, values three times higher than for salmon and which could be explained by the mean weight differences. Very high values were determined in 3 and 40-90 g gilthead seabream [20] with 2296 and $840 \mathrm{mg} \mathrm{N} \cdot \mathrm{kg}^{-1}$ fish $\cdot \mathrm{d}^{-1}$ respectively at $24^{\circ} \mathrm{C}$, which could be explained by the high metabolism level at this temperature.

In our study, the nitrogenous and phosphorous metabolites produced by the seabass, and expressed in relation with the delivered feed, were not size-depen- dent. The TA-N production for seabass was $29.1 \pm$ $6.2 \mathrm{~g} \mathrm{~N} \cdot \mathrm{kg}^{-1}$ feed, and was in accordance with the $30 \mathrm{~g} \mathrm{~N} \cdot \mathrm{kg}^{-1}$ feed frequently reported in the literature for trout [5]. In seabass, excretion was estimated to be $54.9 \pm 4.4 \mathrm{~g}$ Total $-\mathrm{N} \cdot \mathrm{kg}^{-1}$ feed and $5.9 \pm 0.5 \mathrm{~g}$ Total$\mathrm{P} \cdot \mathrm{kg}^{-1}$ feed. Some lower ratios were found in Atlantic salmon: $10-40 \mathrm{~g} \mathrm{~N} \cdot \mathrm{kg}^{-1}$ feed and 2-5 $\mathrm{g} \mathrm{P} \cdot \mathrm{kg}^{-1}$ feed [4], $12-20 \mathrm{~g} \mathrm{~N}^{-\mathrm{kg}^{-1}}$ feed and $5 \mathrm{~g} \mathrm{P} \cdot \mathrm{kg}^{-1}$ feed in $2-4 \mathrm{~kg}$ fish [9].

In 25 to $325 \mathrm{~g}$ seabass, the ammonia excretion represented $30-58 \%$ of the nitrogen intake as shown in this study. Higher values were found by different authors for seabass $56-70 \%$ for $30 \mathrm{~g}$ fish [7]. Lower values were also found by other authors: 30 and $38 \%$ in 11 and $132 \mathrm{~g}$ fish, fed respectively at 1.49 and $0.5 \%$ per day with an experimental diet containing $8.83 \%$ of nitrogen on a dried matter basis [7]; and 30-35\% for $75 \mathrm{~g}$ seabass, fed $1 \%$ with $44-54 \%$ protein pellets [1]. In seabream, 35-37\% was found in 3-90 $\mathrm{g}$ fish fed at $2-2.2 \% \cdot \mathrm{d}^{-1}[20]$. In salmonids, ammonia excretion was either (i) lower: $30-33 \%$ in $380 \mathrm{~g}$ rainbow trout [2] and $35 \%$ in Atlantic salmon post smolts [10]; (ii) at the same level: $30-38 \%$ in brown and rainbow trout [6]; or (iii) higher: $42 \%$ in $150 \mathrm{~g}$ rainbow trout fed $0.5 \%$ with $51 \%$ protein feed [16]. In turbot, ammonia excretion was lower: $20 \%$ in 14 to $179 \mathrm{~g}$ fish fed at $1.48-0.43 \%$ [7].

Nitrogen accretion in seabass was calculated in our study as Fish/Feed, in percentage (table III) and it averaged $14.7 \%$ for batches but only $10.2 \%$ for the whole farm. These values were smaller than those reported from laboratory studies: $49-53 \%$ in the same species, $53-57 \%$ in salmonids, and $64-67 \%$ in turbot [7]. Phosphorus accretion was about $40 \%$ for 3 of the 4 studied batches and $27 \%$ for the whole farm. The results on fish batches are higher than those cited in a bibliographic review which concluded that phosphorus accretion was not higher than $30 \%$ (mean value $=$ $20 \%$ ) in most fish species [6]. These differences in observed $\mathbf{N}$ or $\mathbf{P}$ metabolite productions and in $\mathrm{N}$ or $\mathrm{P}$ accretion with other species could be explained both by the specific metabolism of seabass (where the FCR - feed conversion rate - was 1.8 in seabass farms versus $1.1-1.2$ in salmon farms) and by a rearing temperature $\left(17^{\circ} \mathrm{C}\right)$ different from the agreed optimum for this species $\left(24-25^{\circ} \mathrm{C}\right)$.

There are few references to the total $\mathrm{N}$ or $\mathrm{P}$ budgets in fish farms in the literature, where each term of the equation of mass conservation is determined separately. Most of the time, one term is calculated by difference from the others, as for example the build-up of $\mathrm{N}$ or $\mathrm{P}$ from the biomass gain. This way of doing things always makes the algebraic sum of the terms of the equation equal to zero and loads all experimental errors on to the calculated term. The reality is different when each term is estimated from experimental and field data and the mass equation is generally unbalanced. In our survey, the $\mathrm{N}$ and $\mathrm{P}$ quantity found in biomass gain and wastes is explained by the $\mathrm{N}$ and $\mathrm{P}$ 
present in feed in a range of 83.9-105.2\% and 66.5$104.6 \%$, respectively. These values validate the data presented here even if different factors may have contributed to over- or under-estimation as, for example, the low concentrations of $\mathrm{N}$ or $\mathrm{P}$ sometimes close to the detection limits of the analytical techniques used. Similarly, the proposed equations for waste production (table V), which predict $88 \%$ of Total-N and $94 \%$ of Total-P production measured for the whole farm, are useful tools to estimate wastes from seabass farms. It should be noted that in our budgets, we did not take into account the loss of nitrogen through the atmospheric pathway. Partly due to the short residence time of the water in the batches, the non-accumulation of organic particles on the bottom, and the hyper-oxygenation of the water (125-130\% of saturation), denitrification can be considered as absent. Furthermore, the concentrations of $\mathrm{NH}_{3}$ in the water represent less than $1 \%$ of the concentrations of TA-N (pH 7.3; temperature from 16.5 to $18.5^{\circ} \mathrm{C}$ ). Therefore, $\mathrm{NH}_{3}$ diffusion into the atmosphere (if any) may also be considered negligible. Nevertheless, in order to confirm our results on nitrogenous and phosphorous budgets, where seabass is indicated as a poor nitrogen-retainer, further experiments are needed at laboratory scale and at different temperatures.

\section{Acknowledgements}

The authors thank J. Mélard and J.P. Blancheton for their help and comments.

\section{REFERENCES}

[1] Ballestrazzi R., Lanari D., d'Agaro E., Mion A., The effect of dietary protein level and source on growth body composition total ammonia and reactive phosphate excretion of growing seabass (Dicentrarchus labrax), Aquaculture 127 (1994) 197-206.

[2] Beamish F.W.H., Thomas E., Effects of dietary protein and lipid on nitrogen losses in rainbow trout (Salmo gairdneri), Aquaculture 41 (1984) 359-371.

[3] Benschneider K., Robinson R.J., A new spectrophotometric method for the determination of nitrite in seawater, J. Mar. Res. 1 (1952) 87-86.

[4] Bergheim A., Seymour E.A., Sanni S., Tyvold T., Measurements of oxygen consumption and ammonia excretion of Atlantic salmon (Salmo salar L.) in commercialscale, single-pass freshwater and seawater landbased culture systems, Aquac. Eng. 10 (1991) 251-267.

[5] Dosdat A., L'excrétion chez les poissons téléostéens, I- L'azote, Piscic. Fr. 108 (1995) 25-39.

[6] Dosdat A., L'excrétion chez les poissons téléostéens, II- Le phosphore, Piscic. Fr. 109 (1995) 18-29.

[7] Dosdat A., Servais F., Métailler R., Huelvan C., Desbruyères E., Comparison of nitrogenous losses in five teleost fish species, Aquaculture 141 (1996) 107127.

[8] Eikebrokk B., Ulgenes Y., Characterisation of treated and untreated effluents from landbased fish farms, in: Reinertsen H., Dahle L.A., Jorgensen L., Tvinnereim K. (Eds.), Fish farming technology, Proc. Trondheim, Norway, 9-12 August, Balkema, Rotterdam, 1993, pp. 361-366.

[9] Fivelstad S., Thomassen J.M., Smith M.J., Kjartansonn H., Sando A.B., Metabolite production rates from Atlantic salmon (Salmo salar L.) and arctic charr (Salvelinus alpinus) reared in single pass land-based brackish water and sea water systems, Aquac. Eng. 9 (1990) 1-21.
[10] Forsberg O.I., Ammonia excretion rates from postsmolts Atlantic salmon (Salmo salar L.) in land-based farms, Aquac. Res. 27 (1996) 937-944.

[11] Forster R.P., Goldstein L., Formation of excretory products, in: Hoar W.S., Randall D.J. (Eds.), Fish Physiology, vol. 1, Academic Press, New York, 1969, pp. 313 350.

[12] Handy R.D., Poxton M.G., Nitrogen pollution in mariculture: toxicity and excretion of nitrogenous compounds by marine fish, Rev. Fish Biol. Fishes 3 (1993) 205-241.

[13] Hedges J.I., Stern J.H., Carbon and nitrogen determinations of carbonate-containing solids, Limnol. Oceanogr. 29 (1984) 657-663.

[14] Kaushik S.J., Influence of nutritional status on the daily patterns of nitrogen excretion in the carp (Cyprinus carpio) and the rainbow trout (Salmo gairdneri), Reprod. Nutr. Dev. 20 (1980) 1751-1765.

[15] Kaushik S.J., Nutrition et alimentation des poissons et contrôle des déchets piscicoles, Piscic. Fr. 101 (1990) 14-23.

[16] Kaushik S.J., Gomes E.F., Effect of feeding frequency on nitrogen and energy balance in rainbow trout under maintenance conditions, Aquaculture 73 (1988) 207216.

[17] Koroleff F., Determination of ammonia, in: Grasshof K., Ehrhardt M., Kremling K. (Eds.), Methods of Seawater Analysis, 1983, pp. 150-157.

[18] Lemarié G., Covès D., Dutto G., Gasset E., Person-Le Ruyet J., Chronic toxicity of ammonia for European seabass (Dicentrarchus labrax) juveniles, in: Swanson C., Young P., MacKinley D. (Eds.), Applied environmental physiology of fishes symposium proc., International Congress on the Biology of Fishes, San Francisco State University, 14-18 July, American Fisheries Society, Bethesda ,1996, pp. 65-76.

[19] Murphy J., Riley J.P., A modified single solution method for the determination of phosphate in natural waters, Anal. Chim. Acta 27 (1962) 31-36. 
[20] Porter C.B., Krom M.D., Robbins M.G., Brickell L., Davidson A., Ammonia excretion and total $\mathrm{N}$ budget for gilthead seabream (Sparus aurata) and its effect on water quality conditions, Aquaculture 66 (1987) 287297.

[21] Strickland J.D.H., Parsons T.R., A practical handbook of seawater analysis, Fisheries Research Board of Canada, Ottawa, Bulletin 167, 1972,310 p.
[22] Tréguer P., Le Corre P., Manuel d'analyses des sels nutritifs dans l'eau de mer. Utilisation de l'autoanalyseur II, Technicon®, université de Bretagne Occidentale, Brest, France, 1975, $110 \mathrm{p}$.

[23] Wood E.D., Armstrong F.A.J., Richards F.A., Determination of nitrate in sea water by cadmium copper reduction to nitrite, J. Mar. Biol. Assoc. UK 47 (1967) 2331. 